\title{
Monitoring of Butylated Hydroxyanisole in Food and Wastewater Samples Using Electroanalytical Two-Fold Amplified Sensor
}

\author{
Zahra Arab $^{1}$, Sara Jafarian ${ }^{1, *}$, Hassan Karimi-Maleh ${ }^{2, *}$, , Leila Roozbeh Nasiraie ${ }^{1}\left(\mathbb{C}\right.$ and Mohammad Ahmadi ${ }^{3}$ \\ 1 Food Science Department, Nour Branch, Islamic Azad University, Nour 4641859557, Iran; \\ nazanin.a484@gmail.com (Z.A.); leila_roozbeh@yahoo.com (L.R.N.) \\ 2 Department of Chemical Engineering, Quchan University of Technology, Quchan 9477177870, Iran \\ 3 Food Science \& Technology Department, Ayatollah Amoli Branch, Islamic Azad University, \\ Amol 4615143358, Iran; drahmady@gmail.com \\ * $\quad$ Correspondence: S_jafarian@iaunour.ac.ir (S.J.); h.karimi.maleh@qiet.ac.ir (H.K.-M.); Tel.: +98-9112540112 (H.K.-M.)
}

check for

updates

Citation: Arab, Z.; Jafarian, S.;

Karimi-Maleh, H.; Roozbeh Nasiraie,

L.; Ahmadi, M. Monitoring of

Butylated Hydroxyanisole in Food

and Wastewater Samples Using

Electroanalytical Two-Fold Amplified

Sensor. Sustainability 2022, 14, 2169.

https://doi.org/10.3390/su14042169

Academic Editors: Dario Donno and Marc A. Rosen

Received: 19 November 2021

Accepted: 6 February 2022

Published: 14 February 2022

Publisher's Note: MDPI stays neutral with regard to jurisdictional claims in published maps and institutional affiliations.

Copyright: (c) 2022 by the authors. Licensee MDPI, Basel, Switzerland. This article is an open access article distributed under the terms and conditions of the Creative Commons Attribution (CC BY) license (https:// creativecommons.org/licenses/by/ $4.0 /)$.

\begin{abstract}
A high performance and fast response sensor was fabricated as a monitoring system for the determination of butylated hydroxyanisole (BHA) in food and wastewater samples. In this regard, a carbon paste electrode (CPE) that was amplified with platinum-decorated single wall carbon nanotubes (Pt/SWCNTs) and 1-Butyl-3-methylimidazolium chloride ([C4mim][Cl]) was investigated as a new electroanalytical sensor for the monitoring of BHA in aqueous solution. The $[\mathrm{C} 4 \mathrm{mim}][\mathrm{Cl}] / \mathrm{Pt} / \mathrm{SWCNTs} / \mathrm{CPE}$ offered an excellent catalytic activity on oxidation signal of BHA and enhanced its oxidation current about 5.51 times. In the final step, the standard addition results confirmed the powerful ability of $[\mathrm{C} 4 \mathrm{mim}][\mathrm{Cl}] / \mathrm{Pt} / \mathrm{SWCNTs} / \mathrm{CPE}$ to the monitoring of BHA in different water and food samples with acceptable recovery data.
\end{abstract}

Keywords: butylated hydroxyanisole; Pt/SWCNTs nanocomposite; 1-butyl-3-methylimidazolium chloride

\section{Introduction}

The monitoring of food compounds is one of the major steps in the investigation of food quality [1,2]. There are several ingredients in food products that should be studied before use by customers. For many years, due to the close relationship between food quality and human health, measuring and evaluating food quality has been one of the priorities of global organizations [3]. Here, sensors show a significant role in this field, as they gather relevant information from the quality and safety of food products. These data help to create smart food. On the other hand, many of the biomass-derived materials are highly recommended for the fabrication of electro-analytical tools due to their unique features such as sustainability, regenerative nature, and cost-effectiveness [4]. Therefore, sensors and especially electrochemical sensors are a new approach in analytical systems to achieve sustainability goals. Among food additives, antioxidants have been considered more than other additives due to their many benefits and key roles in improving food quality [5]. Tert-butyl-4-methoxyphenol or butylated hydroxyanisole $\left(\mathrm{C}_{11} \mathrm{H}_{16} \mathrm{O}_{2}\right)$ is one of the more commonly used antioxidant food additives that are permitted for application in approximately 50 countries [6]. According to the US Food and Drug Administration reported data, the presence of $0.02 \% w / w$ of $\mathrm{BHA}$ in the total value food produces is safe and cannot create any problems for human health in low concentrations. However, the National Toxicological Program (NTP) report showed that a high dose of BHA is harmful and can cause cancer. Therefore, controlling the amount of BHA in the food production process is important [7].

Accordingly, measurement methods have been used for many years as a suitable strategy to evaluate the quality of food products [8]. Various measurement methods such as chromatography, spectroscopy, and electrochemical sensors have been proposed to monitor food composition [9-13]. Electrochemical methods have received greater attention 
than the other techniques [14,15]. Butylated hydroxyanisole is a common antioxidant and is added to edible fats and fat-containing foods [6]. Research studies confirm that high doses of BHA in food products can be hazardous for the human body and the monitoring of its concentration is important in food products. Therefore, some analytical methods such as electrochemical sensors [16], fluorimetry [17], gas-liquid chromatography [18], capillary electrophoresis [19], and high performance liquid chromatograpy (HPLC) [20] were suggested for the electrochemical determination of BHA concentrations.

Electrochemical sensors are one of the biggest branches of sensor tools that create a relationship between electrical signals and the concentration of compounds [21-25]. Electrochemical sensors have many benefits in monitoring biological and food products such as fast response, low cost, easy operation, portability, and easy modification compared to other analytical systems [26-29]. Electrochemical sensors can be easily modified to create sensitive and selective analytical instruments for monitoring systems [30-32]. Recently, electrochemical methods have gained a special place in food and pharmaceutical analysis as an alternative to most measurement methods [31,33-35]. The unique features of electrochemical sensors, such as fast measurement speed and the ability to become portable kits, have led most large companies to accept this technique as a suitable strategy [36,37]. The behavior of electrochemical sensors is relative to the modification process [38-40]. In this regard, nanomaterials and ionic liquids have been widely used to modify electrodes [41,42].

Nanomaterials are powerful and strategic materials with unique properties and are useful for different branches of science [43-53]. Due to the unique properties of nanomaterials, extensive research has been conducted on the application of nanomaterials in various sciences such as the food industry, pharmaceutical industry, water-treatment measurement sensors, mechanical engineering, and energy industries [54-61]. Platinumbased nanomaterials have shown high-performance catalytic activity in electrochemical systems [62].

Ionic liquids are a group of organic materials with unique properties and high electrical conductivity that have been widely used in the synthesis of chemicals and the catalysis of various chemical reactions as well as electrochemical sensors $[63,64]$. In recent years, they have been employed as a suitable alternative to paraffin in the manufacture of carbon paste electrodes due to their superior electrical conductivity [64,65]. According to the literature, $[\mathrm{C} 4 \mathrm{mim}][\mathrm{Cl}]$ is a good conductive mediator for the modification of paste electrodes and is the suitable choice for the fabrication of highly sensitive electrochemical sensors [66].

Based on the explanations that are provided in the previous paragraphs, nanomaterials and ionic liquids have been used as suitable modifiers for electrochemical sensors. Numerous scientific reports have shown that the simultaneous use of these modifiers can create unique features for electrochemical sensors.

In this research work, a new and powerful electroanalytical sensor $([\mathrm{C} 4 \mathrm{mim}][\mathrm{Cl}] / \mathrm{Pt} /$ SWCNTs/CPE) was fabricated for monitoring BHA as an antioxidant food additive. The results showed the powerful ability of [C4mim][Cl]/Pt/SWCNTs/CPE for trace level analysis of BHA in food samples. The [C4mim][Cl]/Pt/SWCNTs/CPE can be monitored $\mathrm{BHA}$ in low concentrations with a detection limit of $0.5 \mathrm{nM}$, which is the equivalent to (and in many cases better than) the previously described electrochemical sensors.

\section{Experimental Section}

\subsection{Materials}

Butylated hydroxyanisole $(99.0 \%)$, sodium hydroxide $(99.0 \%)$, and phosphoric acid $(85.0 \%)$ were purchased from Alfa Aesar Company. 1,2-hexadecanediol $(90.0 \%), \mathrm{Pt}(\mathrm{acac})_{2}$, SWCNTs, graphite powder < $150 \mu \mathrm{m}$ (99\%), 1-butyl-3-methylimidazolium chloride, hexane $(\geq 90 \%)$, and ethanol (99\%) were purchased from Sigma-Aldrich Company. The phosphate buffer solution (PBS $0.1 \mathrm{M}$ ) was prepared using phosphate salts such as $\mathrm{NaH}_{2} \mathrm{PO}_{4}$, $\mathrm{Na}_{2} \mathrm{HPO}_{4}, \mathrm{Na}_{3} \mathrm{PO}_{4}$.

$\mathrm{Pt} / \mathrm{SWCNTs}$ was synthesized by the reported procedure in our previously published paper by polyol strategy [62]. 


\subsection{Fabrication of Sensor}

The ratio of graphite powder to $\mathrm{Pt} / \mathrm{SWCNT}$ nanocomposite and also the ratio of [C4mim][Cl] to paraffin oil (as binders) in the fabrication of [C4mim][Cl]/Pt/SWCNTs/CPE were optimized in the presence of BHA. After optimization, the [C4mim][Cl]/Pt/SWCNTs / CPE was prepared by mixing $0.94 \mathrm{~g}$ graphite powder $+0.06 \mathrm{gr} \mathrm{Pt} / \mathrm{SWCNTs}$ in a mortar and pestle in the presence $10 \mathrm{~mL}$ ethanol as a solvent. After evaporation of the ethanol in $40^{\circ} \mathrm{C}$, the suitable amount of paraffin oil and [C4mim][Cl] (8:2 v:v) were added drop wise as binders in a mortar and pestle and hand mixed for $60 \mathrm{~min}$. The obtained paste was transferred into a glass tube with a diameter of $3.0 \mathrm{~mm}$ and connected with Ivium-Vertex as a working electrode by a copper wire. Before recording of any signal, [C4mim][Cl]/Pt/SWCNTs/CPE was polished by white paper.

\subsection{Instruments}

Electrochemical signals were recorded by an electrochemical machine Ivium-Vertex (Netherlands). The recording systems were connected to an $\mathrm{Ag} / \mathrm{AgCl} / \mathrm{KCl}_{\text {sat }}$, Pt wire, and $[\mathrm{C} 4 \mathrm{mim}][\mathrm{Cl}] / \mathrm{Pt} / \mathrm{SWCNTs} / \mathrm{CPE}$ as the reference, counter, and working electrode, respectively. Transmission electron microscope (TEM) model Zeiss-EM10C-100 KV (Germany) was used for morphological investigation.

\subsection{Real Sample Preparation}

Edible oil, orange juice, and wastewater were selected for real sample analysis. The orange juice and wastewater were centrifuged $(3000 \mathrm{rpm})$ and filtered. Afterwards, $5 \mathrm{~mL}$ of the filtered juice or wastewater sample was mixed with phosphate buffer solution $(0.1 \mathrm{M}$ $\mathrm{pH}=7.0$ ) and used for real sample analysis. The edible oil was prepared by mixing $2 \mathrm{~mL}$ of the sample and $20 \mathrm{~mL}$ hexane in an erlenmeyer flask, followed by centrifugation at $3200 \mathrm{rpm}$ for $10 \mathrm{~min}$. Following that, $10 \mathrm{~mL}$ hexane was added to the sample, and the mixture was shaken for $45 \mathrm{~min}$ in the same conditions. In the final step, $2 \mathrm{~mL}$ of the extracted sample was dissolved by $2 \mathrm{~mL}$ pure ethanol and the sample was mixed with phosphate buffer solution and transferred into an electrochemical cell for real sample analysis.

\subsection{Electrochemical Measurement of [C4mim][Cl]/Pt/SWCNTs/CPE}

The $[C 4 \mathrm{mim}][\mathrm{Cl}] / \mathrm{Pt} / \mathrm{SWCNTs} / \mathrm{CPE}$ was polished with white paper. The BHA (0.01 m) solution was prepared by dissolving $0.018 \mathrm{~g}$ BHA into $10.0 \mathrm{~mL}$ of the buffer solution (PBS, $0.1 \mathrm{M}, \mathrm{pH} 7.0)$. The SW voltammograms were recorded in the potential range -0.20 and $+0.75 \mathrm{~V}$ vs. $\mathrm{Ag} / \mathrm{AgCl}$ with a frequency $10 \mathrm{HZ}$. Linear sweep voltammograms were acquired from the solution containing $700 \mu \mathrm{M}$ BHA in the potential range $-0.3-650 \mathrm{mV}$. The plot of net-current vs. concentration was used for the calibration curve plot.

\section{Results}

\subsection{Charactrization of Modified Electrode}

The electrochemical impedance spectroscopic (EIS) method was employed for the characterization of modified and unmodified sensors in the presence of BHA (not shown). The charge transfer resistance $\left(\mathrm{R}_{\mathrm{ct}}\right)$ was detected about $2.70 \mathrm{~K} \Omega, 1.8 \mathrm{~K} \Omega, 1.3 \mathrm{~K} \Omega$, and $0.7 \mathrm{~K} \Omega$ at the surface of CPE, Pt/SWCNTs/CPE, [C4mim][Cl]/CPE, and [C4mim][Cl]/Pt/SWCNTs / $\mathrm{CPE}$, respectively. The moving from $2.7 \mathrm{~K} \Omega$ to $0.8 \mathrm{~K} \Omega$ from $\mathrm{CPE}$ to [C4mim][Cl]/Pt/SWCNTs / CPE confirmed the high electrical conductivity of [C4mim][Cl] and Pt/SWCNTs as two new electro-catalysts.

\section{2. $p H$ Investigation}

The oxidation signal of BHA was recorded in different $\mathrm{pH}$ ranges at the surface of $[\mathrm{C} 4 \mathrm{mim}][\mathrm{Cl}] / \mathrm{Pt} / \mathrm{SWCNTs} / \mathrm{CPE}$ using the square wave voltametric method. The results were depicted in the inset of Figure 1. Using oxidation peak potentials, a linear relationship was observed between the oxidation potential of $\mathrm{BHA}$ and $\mathrm{pH}$ with an equation of $\mathrm{E}=0.0603 \mathrm{pH}+0.7177\left(\mathrm{R}^{2}=0.9987\right)$ that confirmed a $\mathrm{pH}$-dependent reaction according to 
Scheme 1 for redox reaction of BHA in aqueous solutions (Figure 1). As can be seen, with an increasing $\mathrm{pH}$ value, the value of protons in the solution was reduced and the redox process was performed more easily and shifted the potential to lower values.

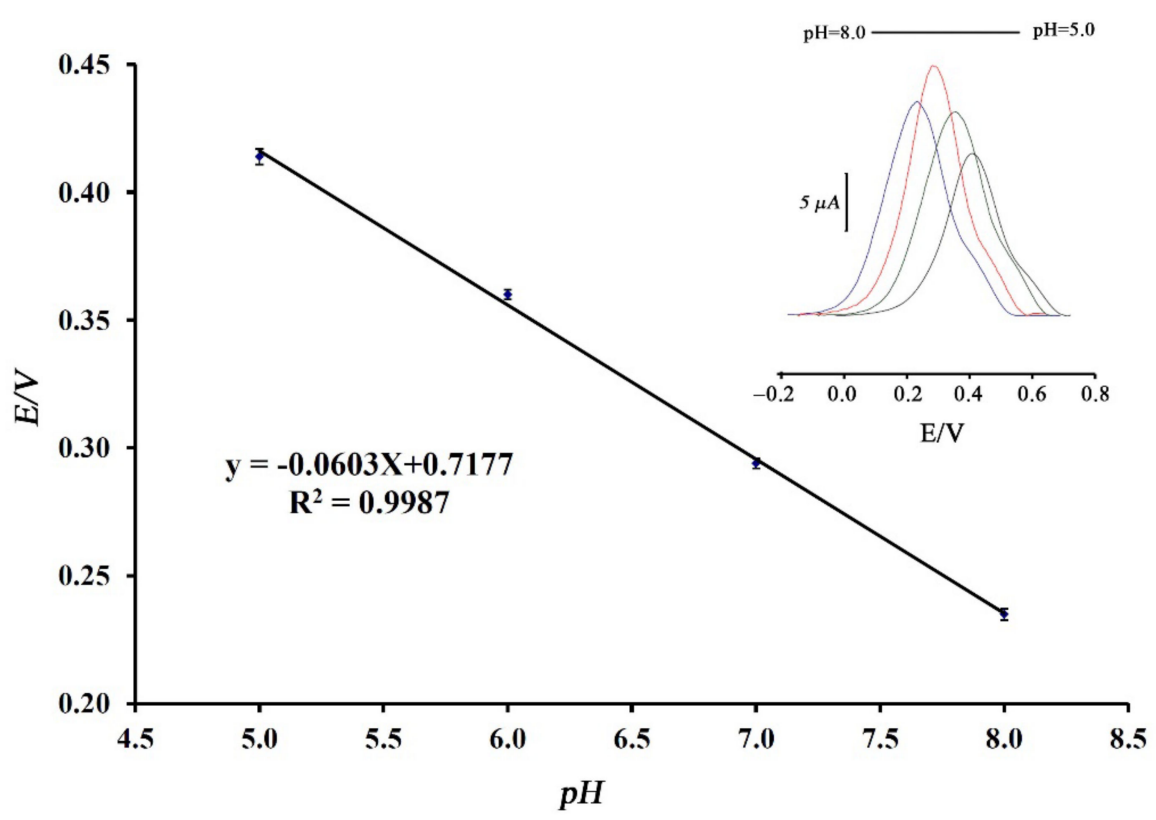

Figure 1. Potential-pH curve for electro-oxidation of BHA at the surface of [C4mim][Cl]/Pt/SWCNTs/CPE. (Inset). Relative SW voltammograms.

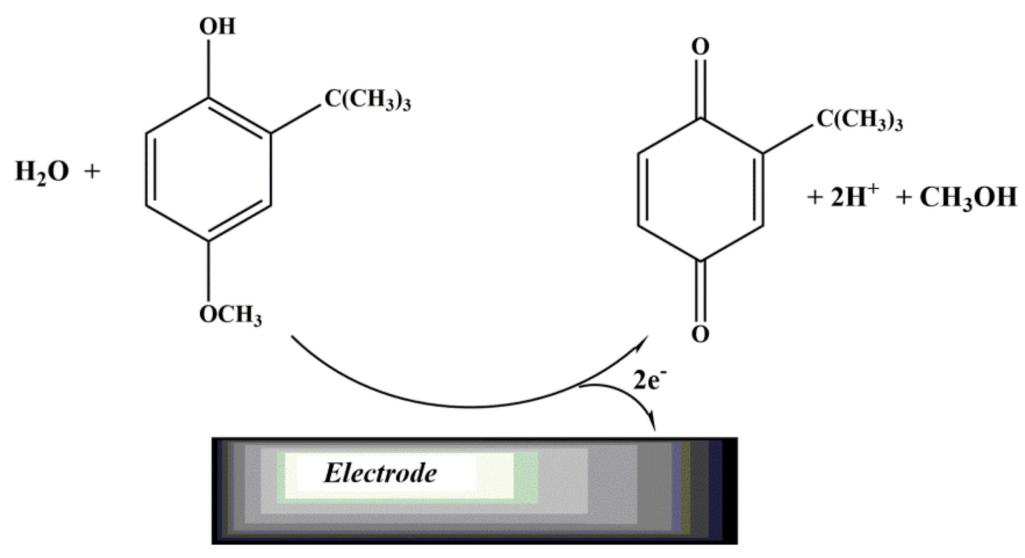

Scheme 1. Redox mechanism of BHA.

On the other hand, the maximum oxidation signal for redox reaction of BHA was observed on $\mathrm{pH}=7.0$ and this condition was used for the next steps (Figure 2).

\subsection{Modification Effect}

The SW voltammograms of BHA were recorded at the surface of the amplified and unmodified electrodes. BHA offered the oxidation currents of $5.66 \mu \mathrm{A}, 13.0 \mu \mathrm{A}, 20.4 \mu \mathrm{A}$, and $31.2 \mu \mathrm{A}$ with the oxidation potentials of $439 \mathrm{mV}, 310 \mathrm{mV}, 312 \mathrm{mV}$, and $285 \mathrm{mV}$ at surface of CPE (curve a), Pt/SWCNTs/CPE (curve b), [C4mim][Cl]/CPE (curve c), and [C4mim][Cl]/Pt/SWCNTs/CPE (curve d), respectively. When comparing the oxidation current and oxidation potential at the surface of CPE with [C4mim][Cl]/Pt/SWCNTs/CPE confirmed an improvement in the current of about 5.51 times and a reduction in the oxidation potential of about $185 \mathrm{mV}$ (Figure 3). These improvements were ascribed to the addition of the conductive mediators ([C4mim] [Cl] and Pt/SWCNTs in this case) at the surface of CPE. Replacing [C4mim][Cl] with paraffin oil and Pt/SWCNTs nanocomposite 
with carbon powder in the sensor greatly increased the electrical conductivity of the electrode surface, creating a sensor with good electrical conductivity. This catalytic property can make it possible to monitor a low concentration of BHA.

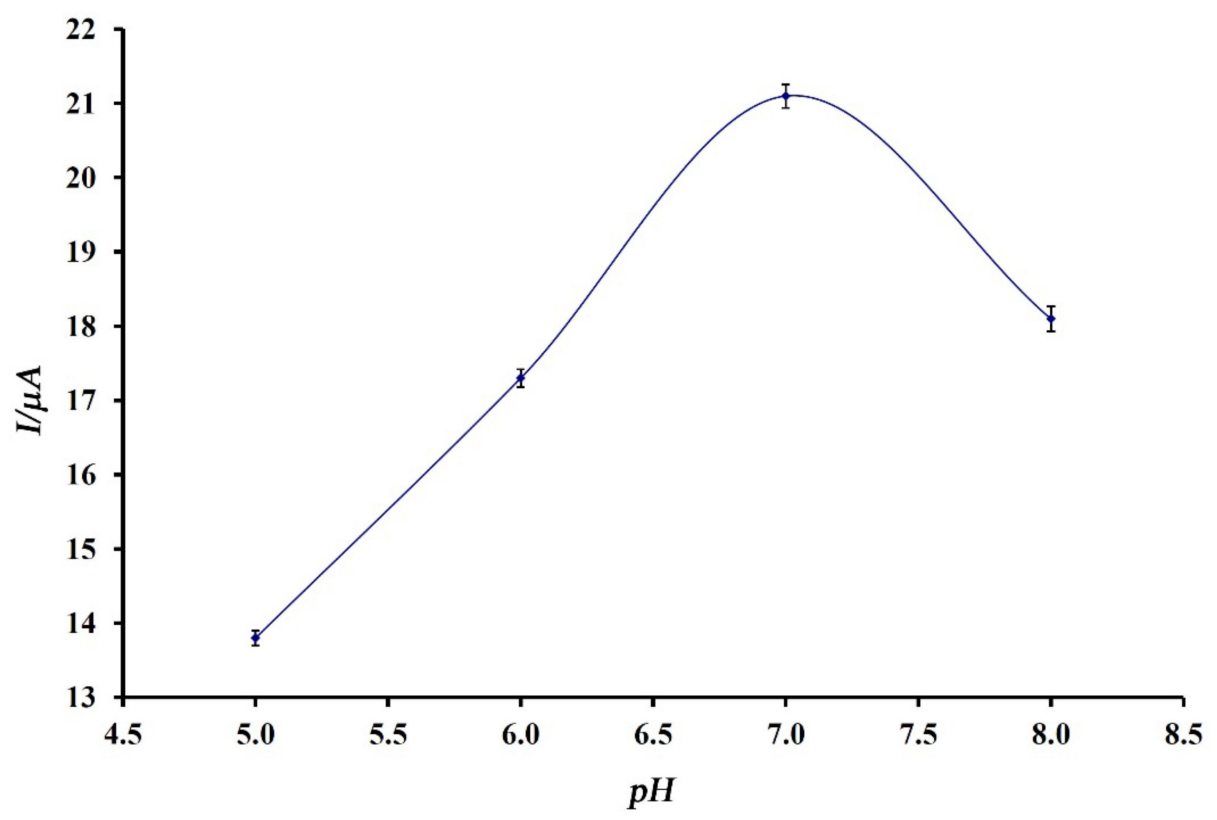

Figure 2. Current-pH curve for electro-oxidation of BHA at the surface of [C4mim][Cl]/Pt/SWCNTs/CPE.

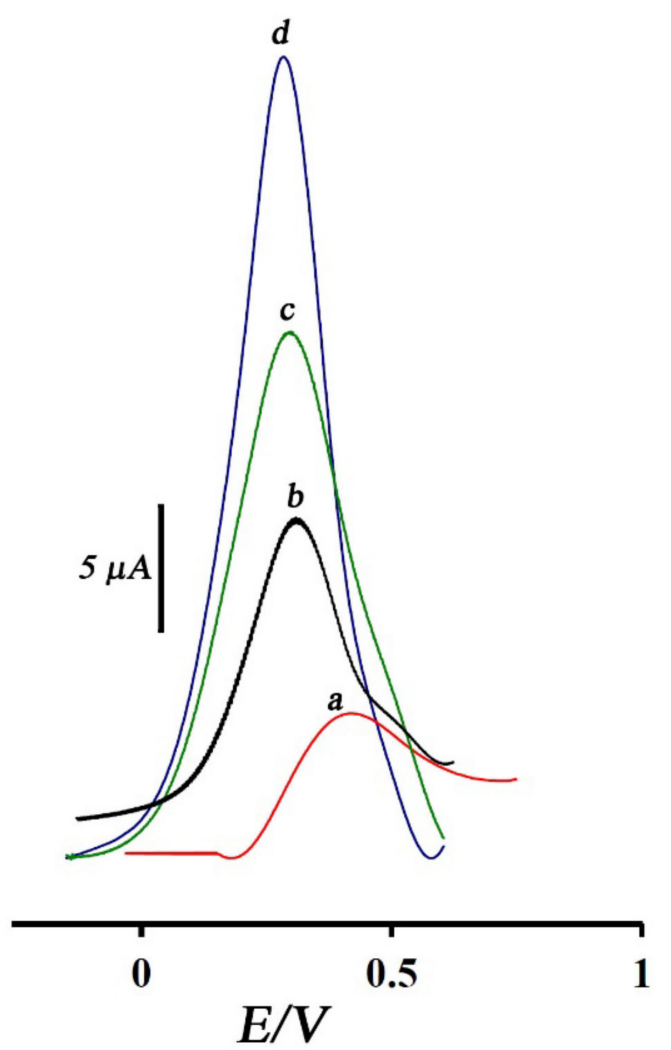

Figure 3. SW voltammograms of BHA at the surface of CPE (a), Pt/SWCNTs/CPE (b), [C4mim][Cl]/CPE (c), and [C4mim][Cl]/Pt/SWCNTs/CPE (d), respectively. 


\subsection{Scan Rate Study and Stability Invesigation}

The linear sweep voltammograms (LSV) of $700 \mu \mathrm{M}$ BHA were recorded in the scan rate range $50-300 \mathrm{mV} / \mathrm{s}$ (Figure 4 inset). The linear relationship between the oxidation current of BHA and $v^{1 / 2}$ with an equation of $I=3.3609 v^{1 / 2}-14.6670\left(R^{2}=0.9979\right)$ in the scan rate range $50-300 \mathrm{mV} / \mathrm{s}$, suggested a diffusion process for redox reaction of BHA at the surface of [C4mim][Cl]/Pt/SWCNTs/CPE (Figure 4).

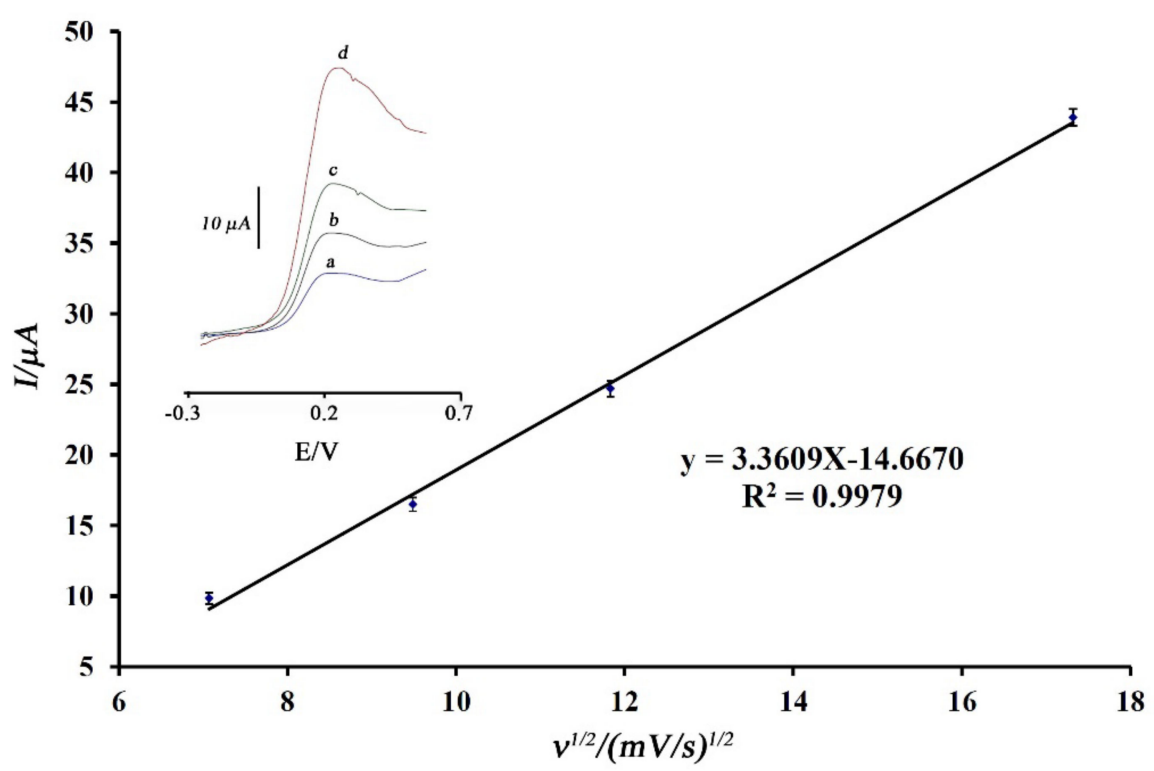

Figure 4. Current $-v^{1 / 2}$ curve for electro-oxidation of $700 \mu \mathrm{M}$ BHA. (Inset) LS voltammograms $700 \mu \mathrm{M}$ BHA at scan rates (a) 50; (b) 90; (c) 140; and (d) $300 \mathrm{mV} / \mathrm{s}$.

The stability of [C4mim][Cl]/Pt/SWCNTs/CPE for monitoring of $240 \mu \mathrm{M}$ BHA was checked over a period of 95 days. The results confirmed that $90 \%$ of the initial signal of BHA remained at the end of the period of three months at surface of the new sensor, confirming the high stability of $[\mathrm{C} 4 \mathrm{mim}][\mathrm{Cl}] / \mathrm{Pt} / \mathrm{SWCNTs} / \mathrm{CPE}$ in monitoring (see Figure 5). The RSD\% value for 11 successive assays of BHA was about $1.1 \%$ using $[\mathrm{C} 4 \mathrm{mim}][\mathrm{Cl}] / \mathrm{Pt} / \mathrm{SWCNTs} / \mathrm{CPE}$ as a sensor. The seven [C4mim][Cl]/Pt/SWCNTs/CPEs were fabricated in the same condition and used for monitoring of $240 \mu \mathrm{M} \mathrm{BHA}$ at $\mathrm{pH}=7.0$. The RSD $\%$ was determined about $2.6 \%$. This point confirmed the good reproducibility of $[\mathrm{C} 4 \mathrm{mim}][\mathrm{Cl}] / \mathrm{Pt} / \mathrm{SWCNTs} / \mathrm{CPE}$ for the monitoring of BHA.

\subsection{Analytical Investigation}

The application of [C4mim][Cl]/Pt/SWCNTs/CPE for the determination of BHA was checked in this step by the square wave voltammetric (SWV) method (Figure 6). The results showed that the oxidation signal of BHA had a linear relationship with its concentration with the equation of $I=0.1209 C+2.2790\left(R^{2}=0.9966\right)$ in the range of $1.0-300 \mu \mathrm{M}$. On the other hand, the sensor showed a detection limit $\left(\mathrm{LOD}=3 \mathrm{~S}_{\mathrm{b}} / \mathrm{m}\right)$ of $0.5 \mathrm{nM}$ and LOQ of $1.5 \mathrm{nM}$ for the monitoring of BHA at the optimum conditions. These LDR and LOD values for $[\mathrm{C} 4 \mathrm{mim}][\mathrm{Cl}] / \mathrm{Pt} / \mathrm{SWCNTs} / \mathrm{CPE}$ monitoring of BHA were comparable to, and in some cases, were better than the prior recommended sensors (see Table 1).

\subsection{Selectivity Investigation}

In this stage, the selectivity of [C4mim][Cl]/Pt/SWCNTs/CPE for monitoring $10 \mathrm{M}$ BHA was investigated in the presence of certain food and inorganic substances. The results were displayed in Table 2 with an acceptable error rate of $5 \%$ in current. As can be seen, the $[\mathrm{C} 4 \mathrm{mim}][\mathrm{Cl}] / \mathrm{Pt} / \mathrm{SWCNTs} / \mathrm{CPE}$ showed a good selectivity for the monitoring of BHA in an aqueous solution. 


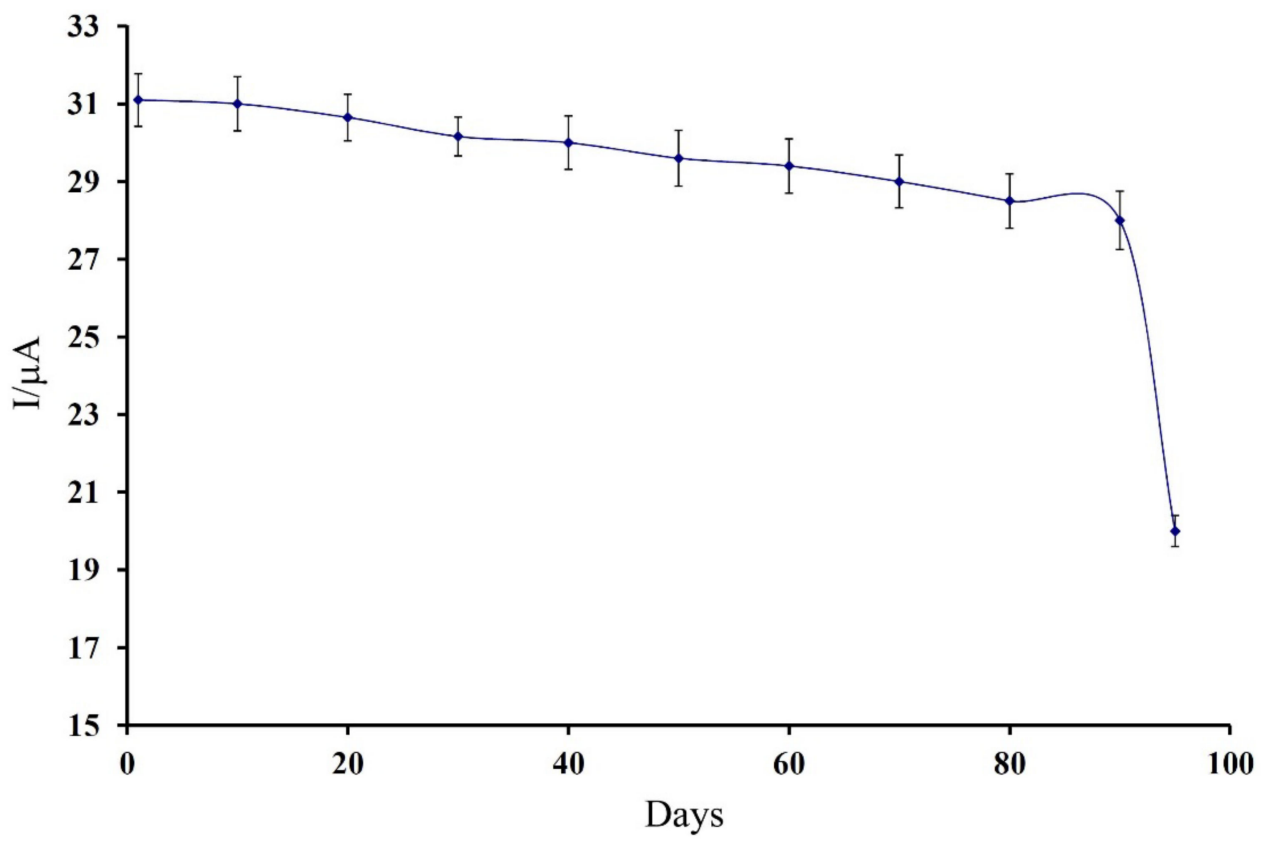

Figure 5. Stability diagram of BHA at surface of $[\mathrm{C} 4 \mathrm{mim}][\mathrm{Cl}] / \mathrm{Pt} / \mathrm{SWCNTs} / \mathrm{CPE}(\mathrm{n}=4.0)$.

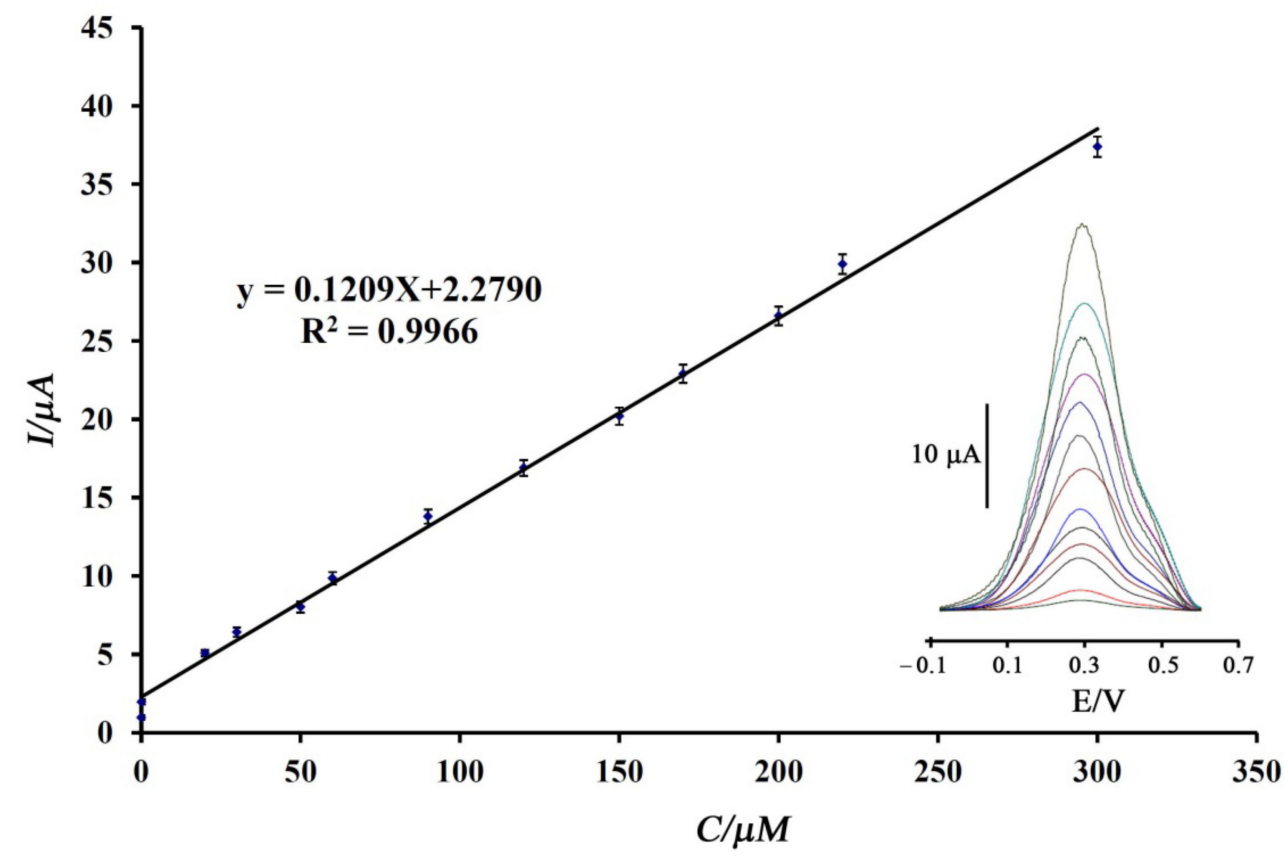

Figure 6. Current-concentration curve for electro-oxidation of $\mathrm{BHA}$ at the surface of $[\mathrm{C} 4 \mathrm{mim}][\mathrm{Cl}] / \mathrm{Pt}$ / SWCNTs/CPE $(\mathrm{n}=4.0)$. (Inset). The relative SW voltammograms in the range of 1.0-300 $\mu \mathrm{M}$.

\subsection{Real Sample Analysis}

The capability of [C4mim][Cl]/Pt/SWCNTs/CPE for the monitoring of BHA in the real samples was checked by the standard addition methods. For this propose, edible oil and orange juice were selected and prepared according to reported procedure in Section 2. The results were tabulated in Table 3, and the recovery range of 98.25-104.3\% confirmed the capability of $[\mathrm{C} 4 \mathrm{mim}][\mathrm{Cl}] / \mathrm{Pt} / \mathrm{SWCNTs} / \mathrm{CPE}$ as new analytical tool for the monitoring of BHA in real samples. 
Table 1. Comparing the sensing ability of [C4mim][Cl]/Pt/SWCNTs/CPE with previously reported sensors for the monitoring of BHA.

\begin{tabular}{ccccc}
\hline Electrode & Mediator & LOD $(\mu \mathbf{M})$ & LDR $(\mu \mathbf{M})$ & Ref. \\
\hline Glassy carbon electrode & Poly L-cysteine & 0.1 & $1.0-10.0$ & {$[67]$} \\
Platinum & Multiwalled carbon nanotube & 0.094 & $0.1-1.0$ & {$[68]$} \\
Graphite & Manganese (II) hexacyanoferate & 0.05 & $0.49-142$ & {$[69]$} \\
Paraffin wax impregnated graphite & O-cresolphthalein complexone (OC) & 0.11 & $0.33-110$ & {$[70]$} \\
Carbon paste & over the multiwalled carbon nanotubes & 0.0005 & $0.001-300$ & This work \\
\hline
\end{tabular}

Table 2. Selectivity of [C4mim][Cl]/Pt/SWCNTs/CPE for the monitoring of BHA.

\begin{tabular}{cc}
\hline Species & Tolerance Limits $\left(\mathbf{W}_{\text {Substance }} / \mathbf{W}_{\mathbf{B H A}}\right)$ \\
\hline glucose, citric acid, and fructose & 400 \\
Starch & saturation \\
$\mathrm{SCN}^{-}, \mathrm{Br}^{-}, \mathrm{Ca}^{2+}, \mathrm{K}^{+}, \mathrm{Na}^{+}$ & 1000 \\
glycine, lucine, phenylalanine & 500 \\
\hline
\end{tabular}

Table 3. Real sample analysis of BHA using [C4mim][Cl]/Pt/SWCNTs/CPE.

\begin{tabular}{ccccc}
\hline Sample & BHA Added $(\mu \mathbf{M})$ & BHA Expected $(\mu \mathbf{M})$ & BHA Founded $(\mu \mathbf{M})$ & Recovery $\%$ \\
\hline Orange juice & - & - & $<$ LOD & - \\
& 10.00 & 10.00 & $10.43 \pm 0.87$ & 104.3 \\
Edible oil & - & - & $<$ LOD & - \\
\multirow{2}{*}{ Wastewater } & 20.00 & - & $19.65 \pm 0.98$ & 98.25 \\
& 15.00 & 15.00 & $<$ LOD & - \\
& & $15.63 \pm 0.79$ & 104.2 \\
\hline
\end{tabular}

\section{Conclusions}

A novel, powerful, and fast analytical sensor was fabricated for the monitoring of BHA in the aqueous solutions. In this regard, CPE was amplified with [C4mim][Cl] and $\mathrm{Pt} / \mathrm{SWCNTs}$ and employed for electrochemical determination of BHA in the concentration range of 1.0-300 $\mu \mathrm{M}$. The [C4mim] [Cl]/Pt/SWCNTs/CPE showed a high catalytic activity on the oxidation signal of BHA and improved the redox reaction of this antioxidant under optimum conditions. In the final step, [C4mim][Cl]/Pt/SWCNTs/CPE was successfully used for the monitoring BHA in different food and wastewater samples with acceptable recovery data.

Author Contributions: Methodology, L.R.N.; formal analysis, Z.A.; writing-original draft preparation, H.K.-M.; writing-review and editing, M.A.; supervision and project administration, S.J. All authors have read and agreed to the published version of the manuscript.

Funding: This research received no external funding.

Institutional Review Board Statement: Not applicable.

Informed Consent Statement: Not applicable.

Data Availability Statement: Not applicable.

Conflicts of Interest: The authors declare no conflict of interest.

\section{References}

1. Mustafa, F.; Andreescu, S. Chemical and biological sensors for food-quality monitoring and smart packaging. Foods 2018, 7, 168. [CrossRef]

2. Kuswandi, B.; Wicaksono, Y.; Abdullah, A.; Heng, L.Y.; Ahmad, M. Smart packaging: Sensors for monitoring of food quality and safety. Sens. Instrum. Food Qual. Saf. 2011, 5, 137-146. [CrossRef] 
3. Wang, N.; Zhang, N.; Wang, M. Wireless sensors in agriculture and food industry-Recent development and future perspective. Comput. Electron. Agric. 2006, 50, 1-14. [CrossRef]

4. Benny, L.; John, A.; Varghese, A.; Hegde, G.; George, L. Waste elimination to porous carbonaceous materials for the application of electrochemical sensors: Recent developments. J. Clean. Prod. 2021, 290, 125759. [CrossRef]

5. Tinggi, U. Selenium: Its role as antioxidant in human health. Environ. Health Prev. Med. 2008, 13, 102-108. [CrossRef] [PubMed]

6. Verhagen, H.; Schilderman, P.A.; Kleinjans, J.C. Butylated hydroxyanisole in perspective. Chem. Biol. Interact. 1991, 80, 109-134. [CrossRef]

7. Leslie, S.W.; Gad, S.C.; Acosta, D. Cytotoxicity of butylated hydroxytoluene and butylated hydroxyanisole in cultured heart cells. Toxicology 1978, 10, 281-289. [CrossRef]

8. Mustafa, F.; Andreescu, S. Nanotechnology-based approaches for food sensing and packaging applications. RSC Adv. 2020, 10, 19309-19336. [CrossRef]

9. Boyce, M.C. Simultaneous determination of antioxidants, preservatives and sweeteners permitted as additives in food by mixed micellar electrokinetic chromatography. J. Chromatogr. A 1999, 847, 369-375. [CrossRef]

10. Cozzolino, D. Infrared spectroscopy as a versatile analytical tool for the quantitative determination of antioxidants in agricultural products, foods and plants. Antioxidants 2015, 4, 482-497. [CrossRef]

11. Alizadeh, M.; Mehmandoust, M.; Nodrat, O.; Salmanpour, S.; Erk, N. A glassy carbon electrode modified based on molybdenum disulfide for determination of folic acid in the real samples. J. Food Meas. Charact. 2021, 15, 5622-5629. [CrossRef]

12. Mehmandoust, M.; Erk, N.; Alizadeh, M.; Salmanpour, S. Voltammetric carbon nanotubes based sensor for determination of tryptophan in the milk sample. J. Food Meas. Charact. 2021, 15, 5288-5295. [CrossRef]

13. Tajik, S.; Orooji, Y.; Karimi, F.; Ghazanfari, Z.; Beitollahi, H.; Shokouhimehr, M.; Varma, R.S.; Jang, H.W. High performance of screen-printed graphite electrode modified with Ni-Mo-MOF for voltammetric determination of amaranth. J. Food Meas. Charact. 2021, 15, 4617-4622. [CrossRef]

14. Fu, L.; Chen, F.; Zhao, S.; Yu, J.; Karimi-Maleh, H.; Lin, C.-T. Analysis of coumarin in food and plant tissue without extraction based on voltammetry of microparticles. J. Food Meas. Charact. 2021, 15, 5439-5444. [CrossRef]

15. Zabihpour, T.; Shahidi, S.-A.; Karimi-Maleh, H.; Ghorbani-HasanSaraei, A. Voltammetric food analytical sensor for determining vanillin based on amplified NiFe 2 O 4 nanoparticle/ionic liquid sensor. J. Food Meas. Charact. 2020, 14, 1039-1045. [CrossRef]

16. Karimi, F.; Bijad, M.; Farsi, M.; Vahid, A.; Asari-Bami, H.; Wen, Y.; Ganjali, M.R. A new nanostructure square wave voltammetric platform for determination of tert-butylhydroxyanisole in food samples. Curr. Anal. Chem. 2019, 15, 172-176. [CrossRef]

17. Hurtubise, R.; Latz, H.W. Fluorimetric determination of butylated hydroxy anisole in food products and packaging material. J. Agric. Food Chem. 1970, 18, 377-380. [CrossRef] [PubMed]

18. Buttery, R.; Stuckey, B. Food Antioxidants, Determination of Butylated Hydroxyanisole and Butylated Hydroxytoluene in Potato Granules by Gas-Liquid Chromatography. J. Agric. Food Chem. 1961, 9, 283-285. [CrossRef]

19. Xiang, Q.; Gao, Y.; Xu, Y.; Wang, E. Capillary electrophoresis-amperometric determination of antioxidant propyl gallate and butylated hydroxyanisole in foods. Anal. Sci. 2007, 23, 713-717. [CrossRef]

20. Yankah, V.V.; Ushio, H.; Ohshima, T.; Koizumi, C. Quantitative determination of butylated hydroxyanisole, butylated hydroxytoluene, and tert-butyl hydroquinone in oils, foods, and biological fluids by high-performance liquid chromatography with fluorometric detection. Lipids 1998, 33, 1139-1145. [CrossRef]

21. Mehmandoust, M.; Erk, N.; Karaman, C.; Karimi, F.; Salmanpour, S. Sensitive and selective electrochemical detection of epirubicin as anticancer drug based on nickel ferrite decorated with gold nanoparticles. Micromachines 2021, 12, 1334. [CrossRef]

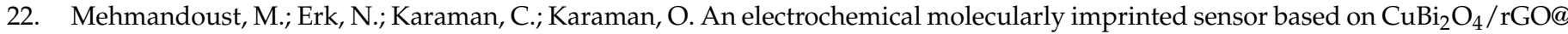
$\mathrm{MoS}_{2}$ nanocomposite and its utilization for highly selective and sensitive for linagliptin assay. Chemosphere 2021, $291,132807$. [CrossRef]

23. Senturk, H.; Eksin, E.; Zeybek, U.; Erdem, A. Detection of Senecionine in Dietary Sources by Single-Use Electrochemical Sensor. Micromachines 2021, 12, 1585. [CrossRef] [PubMed]

24. Fu, L.; Zheng, Y.; Zhang, P.; Lai, G. Quantification of silicon in rice based on an electrochemical sensor via an amplified electrocatalytic strategy. Micromachines 2021, 12, 1048. [CrossRef]

25. Moghadam, F.H.; Taher, M.A.; Agheli, H. Electroanalytical Monitoring of Glutathione in Biological Fluids Using Novel Pt/SWCNTs-Ionic Liquid Amplified Sensor. Top. Catal. 2022. [CrossRef]

26. Yang, R.; Fan, B.; Wang, S.a.; Li, L.; Li, Y.; Li, S.; Zheng, Y.; Fu, L.; Lin, C.-T. Electrochemical Voltammogram Recording for Identifying Varieties of Ornamental Plants. Micromachines 2020, 11, 967. [CrossRef] [PubMed]

27. Low, S.S.; Ji, D.; Chai, W.S.; Liu, J.; Khoo, K.S.; Salmanpour, S.; Karimi, F.; Deepanraj, B.; Show, P.L. Recent Progress in Nanomaterials Modified Electrochemical Biosensors for the Detection of MicroRNA. Micromachines 2021, 12, 1409. [CrossRef] [PubMed]

28. Zhao, L. Horseradish Peroxidase Labelled-Sandwich Electrochemical Sensor Based on Ionic Liquid-Gold Nanoparticles for Lactobacillus brevis. Micromachines 2021, 12, 75. [CrossRef]

29. Sohrabi, H.; Majidi, M.R.; Arbabzadeh, O.; Khaaki, P.; Pourmohammad, S.; Khataee, A.; Orooji, Y. Recent advances in the highly sensitive determination of zearalenone residues in water and environmental resources with electrochemical biosensors. Environ. Res. 2022, 204, 112082. [CrossRef] [PubMed] 
30. Salmanpour, S.; Abbasghorbani, M.; Karimi, F.; Bavandpour, R.; Wen, Y. Electrocatalytic determination of cysteamine uses a nanostructure based electrochemical sensor in pharmaceutical samples. Curr. Anal. Chem. 2017, 13, 40-45. [CrossRef]

31. John, A.; Benny, L.; Cherian, A.R.; Narahari, S.Y.; Varghese, A.; Hegde, G. Electrochemical sensors using conducting polymer/noble metal nanoparticle nanocomposites for the detection of various analytes: A review. J. Nanostruct. Chem. 2021, 11, 1-31 [CrossRef]

32. Mehmandoust, M.; Çakar, S.; Özacar, M.; Salmanpour, S.; Erk, N. Electrochemical sensor for facile and highly selective determination of antineoplastic agent in real samples using glassy carbon electrode modified by 2D-MoS $2 \mathrm{NFs} / \mathrm{TiO} 2 \mathrm{NPs}$. Top. Catal. 2021. [CrossRef]

33. Karimi-Maleh, H.; Karimi, F.; Fu, L.; Sanati, A.L.; Alizadeh, M.; Karaman, C.; Orooji, Y. Cyanazine herbicide monitoring as a hazardous substance by a DNA nanostructure biosensor. J. Hazard. Mater. 2022, 423, 127058. [CrossRef] [PubMed]

34. Alizadeh, M.; Azar, P.A.; Mozaffari, S.A.; Karimi-Maleh, H.; Tamaddon, A.-M. A DNA based biosensor amplified with ZIF-8/ionic liquid composite for determination of mitoxantrone anticancer drug: An experimental/docking investigation. Front. Chem. 2020, 8, 814. [CrossRef]

35. Koshki, M.-S.; Baghayeri, M.; Fayazi, M. Application of sepiolite/FeS2 nanocomposite for highly selective detection of mercury (II) based on stripping voltammetric analysis. J. Food Meas. Charact. 2021, 15, 5318-5325. [CrossRef]

36. Moghaddam, A.; Zamani, H.A.; Karimi-Maleh, H. A New Electrochemical Platform for Dasatinib Anticancer Drug Sensing Using $\mathrm{Fe}_{3} \mathrm{O}_{4}$-SWCNTs/Ionic Liquid Paste Sensor. Micromachines 2021, 12, 437. [CrossRef]

37. Salmanpour, S.; Karimi, F.; Khalilzadeh, M.A.; Gupta, V.K.; Keyvanfard, M.; Bagheri, H. Liquid phase determination of isuprel in pharmaceutical and biological samples using a nanostructure modified carbon paste electrode. J. Mol. Liq. 2015, 201, 108-112. [CrossRef]

38. Karimi-Maleh, H.; Khataee, A.; Karimi, F.; Baghayeri, M.; Fu, L.; Rouhi, J.; Karaman, C.; Karaman, O.; Boukherroub, R. A green and sensitive guanine-based DNA biosensor for idarubicin anticancer monitoring in biological samples: A simple and fast strategy for control of health quality in chemotherapy procedure confirmed by docking investigation. Chemosphere 2021, $291,132928$. [CrossRef]

39. Gupta, V.K.; Karimi-Maleh, H.; Sadegh, R. Simultaneous determination of hydroxylamine, phenol and sulfite in water and waste water samples using a voltammetric nanosensor. Int. J. Electrochem. Sci. 2015, 10, 303-316.

40. Fouladgar, M. CuO-CNT nanocomposite/ionic liquid modified sensor as new breast anticancer approach for determination of doxorubicin and 5-fluorouracil drugs. J. Electrochem. Soc. 2018, 165, B559. [CrossRef]

41. Moshirian-Farahi, S.S.; Zamani, H.A.; Abedi, M. Nano-molar level determination of isoprenaline in pharmaceutical and clinical samples; A nanostructure electroanalytical strategy. Eurasian Chem. Commun. 2020, 2, 702-711. [CrossRef]

42. Hussain, R.T.; Islam, A.S.; Khairuddean, M.; Suah, F.B.M. A polypyrrole/GO/ZnO nanocomposite modified pencil graphite electrode for the determination of andrographolide in aqueous samples. Alex. Eng. J. 2021, 61, 4209-4218.

43. Deeksha, B.; Sadanand, V.; Hariram, N.; Rajulu, V. Preparation and properties of cellulose nanocomposite fabrics with in situ generated silver nanoparticles by bioreduction method. J. Bioresour. Bioprod. 2021, 6, 75-81.

44. Cheng, Z.; Meng, J.; Wang, X. Preparation of wood-based filter loaded with Ag nanoparticles and its catalytic degradation performance on organic dye. J. For. Eng. 2020, 5, 94-98.

45. Pyrzynska, K.; Sentkowska, A. Biosynthesis of selenium nanoparticles using plant extracts. J. Nanostruct. Chem. 2021. [CrossRef]

46. Nangare, S.N.; Patil, S.R.; Patil, A.G.; Khan, Z.G.; Deshmukh, P.K.; Tade, R.S.; Mahajan, M.R.; Bari, S.B.; Patil, P.O. Structural design of nanosize-metal-organic framework-based sensors for detection of organophosphorus pesticides in food and water samples: Current challenges and future prospects. J. Nanostruct. Chem. 2021. [CrossRef]

47. Xia, H.; Jiahuan, A.N.; Zhang, W.; GE, C.; Zuo, S. Effect of the metal-support interaction on catalytic oxidation performances of HMF on Ag nanoparticles. J. For. Eng. 2020, 5, 88-93.

48. Muhammad, T.; Waqas, H.; Manzoor, U.; Farooq, U.; Rizvi, Z.F. On doubly stratified bioconvective transport of Jeffrey nanofluid with gyrotactic motile microorganisms. Alex. Eng. J. 2022, 61, 1571-1583. [CrossRef]

49. Bai, S.; Han, C.; Ni, Z.; Ni, Y.; Lyu, Y.; Ye, X. Effect of polyethylene glycol(PEG)on properties of the surface modified cellulose nanofiber(CNF)/polylactic acid(PLA)composite. J. For. Eng. 2020, 5, 62-68.

50. Rajabi, M.; Moradi, O.; Mazlomifar, A. Adsorption of methyl orange dye from water solutions by carboxylate group functionalized multi-walled carbon nanotubes. Int. J. Nano Dimens. 2015, 6, 227-240.

51. Zhang, Y.; Wei, L.; Lu, L.; Gan, L.; Pan, M. Adsorption-photocatalytic properties of cellulose nanocrystal supported ZnO nanocomposites. J. For. Eng. 2020, 5, 29-35.

52. Keyikoglu, R.; Khataee, A.; Lin, H.; Orooji, Y. Vanadium (V)-doped ZnFe LDH for enhanced sonocatalytic degradation of pymetrozine. Chem. Eng. J. 2022, 434, 134730. [CrossRef]

53. Taherian, Z.; Gharahshiran, V.S.; Khataee, A.; Orooji, Y. Synergistic effect of freeze-drying and promoters on the catalytic performance of $\mathrm{Ni} / \mathrm{MgAl}$ layered double hydroxide. Fuel 2021, 311, 122620. [CrossRef]

54. Miao, X.; Lin, J.; Bian, F. Utilization of discarded crop straw to produce cellulose nanofibrils and their assemblies. J. Bioresour. Bioprod. 2020, 5, 26-36. [CrossRef]

55. Korkmaz, S.; Kariper, İ.A.; Karaman, O.; Karaman, C. The production of rGO/RuO2 aerogel supercapacitor and analysis of its electrochemical performances. Ceram. Int. 2021, 47, 34514-34520. [CrossRef] 
56. Yorseng, K.; Siengchin, S.; Ashok, B.; Rajulu, A.V. Nanocomposite Egg Shell Powder with in situ Generated Silver Nanoparticles Using Inherent Collagen as Reducing Agent. J. Bioresour. Bioprod. 2020, 5, 101-107. [CrossRef]

57. Babu, A.M.; Rajeev, R.; Thadathil, D.A.; Varghese, A.; Hegde, G. Surface modulation and structural engineering of graphitic carbon nitride for electrochemical sensing applications. J. Nanostruct. Chem. 2021. [CrossRef]

58. Karaman, C. Orange Peel Derived-Nitrogen and Sulfur Co-doped Carbon Dots: A Nano-booster for Enhancing ORR Electrocatalytic Performance of 3D Graphene Networks. Electroanalysis 2021, 33, 1356-1369. [CrossRef]

59. Akça, A.; Karaman, O.; Karaman, C. Mechanistic insights into catalytic reduction of N2O by CO over Cu-embedded graphene: A density functional theory perspective. ECS J. Solid State Sci. Technol. 2021, 10, 041003. [CrossRef]

60. Arefi-Oskoui, S.; Khataee, A.; Behrouz, S.J.; Vatanpour, V.; Gharamaleki, S.H.; Orooji, Y.; Safarpour, M. Development of MoS 2 /OMWCNTs/PES blended membrane for efficient removal of dyes, antibiotic, and protein. Sep. Purif. Technol. 2022, $280,119822$. [CrossRef]

61. Taherian, Z.; Khataee, A.; Han, N.; Orooji, Y. Hydrogen production through methane reforming processes using promoted$\mathrm{Ni} /$ mesoporous silica: A review. J. Ind. Eng. Chem. 2021. [CrossRef]

62. Karimi-Maleh, H.; Alizadeh, M.; Orooji, Y.; Karimi, F.; Baghayeri, M.; Rouhi, J.; Tajik, S.; Beitollahi, H.; Agarwal, S.; Gupta, V.K. Guanine-based DNA biosensor amplified with Pt/SWCNTs nanocomposite as analytical tool for nanomolar determination of daunorubicin as an anticancer drug: A docking/experimental investigation. Ind. Eng. Chem. Res. 2021, 60, 816-823. [CrossRef]

63. Bijad, M.; Karimi-Maleh, H.; Farsi, M.; Shahidi, S.-A. An electrochemical-amplified-platform based on the nanostructure voltammetric sensor for the determination of carmoisine in the presence of tartrazine in dried fruit and soft drink samples. J. Food Meas. Charact. 2018, 12, 634-640. [CrossRef]

64. Opallo, M.; Lesniewski, A. A review on electrodes modified with ionic liquids. J. Electroanal. Chem. 2011, 656, 2-16. [CrossRef]

65. Wei, D.; Ivaska, A. Applications of ionic liquids in electrochemical sensors. Anal. Chim. Acta 2008, 607, 126-135. [CrossRef]

66. Zabihpour, T.; Shahidi, S.-A.; Karimi Maleh, H.; Ghorbani-HasanSaraei, A. $\mathrm{MnFe}_{2} \mathrm{O}_{4} / 1$-Butyl-3-methylimidazolium hexafluorophosphate modified carbon paste electrode: An amplified food sensor for determination of gallic acid in the presence of ferulic acid as two phenolic antioxidants. Eurasian Chem. Commun. 2020, 2, 362-373.

67. Thomas, D.; Rasheed, Z.; Jagan, J.S.; Kumar, K.G. Study of kinetic parameters and development of a voltammetric sensor for the determination of butylated hydroxyanisole (BHA) in oil samples. J. Food Sci. Technol. 2015, 52, 6719-6726. [CrossRef] [PubMed]

68. Rasheed, Z.; Vikraman, A.E.; Thomas, D.; Jagan, J.S.; Kumar, K.G. Carbon-nanotube-based sensor for the determination of butylated hydroxyanisole in food samples. Food Anal. Methods 2015, 8, 213-221. [CrossRef]

69. Jayasri, D.; Narayanan, S.S. Manganese (II) hexacyanoferrate based renewable amperometric sensor for the determination of butylated hydroxyanisole in food products. Food Chem. 2007, 101, 607-614. [CrossRef]

70. Manoranjitham, J.J.; Narayanan, S.S. Electrochemical sensor for determination of butylated hydroxyanisole (BHA) in food products using poly O-cresolphthalein complexone coated multiwalled carbon nanotubes electrode. Food Chem. 2021, $342,128246$. [CrossRef] 